\title{
THE FACTORS AFFECTING NOMINAL EXCHANGE RATE FOR DEVELOPING COUNTRIES: A PANEL DATA ANALYSIS ${ }^{1}$
}

$* * *$

\section{GELISSMEKTE OLAN ÜLKELERDE NOMINAL DÖVİZ KURUNU BELİRLEYEN FAKTÖRLER: BİR PANEL DATA ANALIZİ}

\author{
Doç. Dr. Banu DEMIRHAN \\ Afyon Kocatepe Üniversitesi \\ Afyon Meslek Yüksek Okulu \\ İşletme Yönetimi Programı \\ bdemirhan@aku.edu.tr \\ ORCID: 0000-0002-0902-4629
}
Prof. Dr. Erdal DEMIRHAN
Afyon Kocatepe Üniversitesi İktisadi ve İdari Bilimler Fakültesi
İktisat Bölümü
demirhan@aku.edu.tr
ORCID: 0000-0001-6843-1868

\begin{abstract}
Increases in nominal exchange rates lead to crucial economic problems in developing countries. Therefore, in these countries, economic policies focus on eliminating the reasons of increases in nominal exchange rates. This study examines the factors determining nominal exchange rate in 77 developing countries for the period of 2004 2016. Panel data regression model is constructed in the econometric estimations. According to empirical results, anti-inflationary policies are necessary to achieve lower nominal exchange rates in developing countries. Economic growth leads to higher nominal exchange rates. Economic policies towards increasing international reserves contribute to lower nominal exchange rates.
\end{abstract}

Keywords: Nominal Exchange Rate, Economic Growth, Panel Data Regression Model

\section{$\ddot{\mathbf{O z}}$}

Gelişmekte olan ülkelerde döviz kurlarındaki artış önemli ekonomik sorunlara yol açmaktadır. Bu bakımdan bu ülkelerde ekonomi politikaları nominal döviz kurlarındaki artışların nedenlerinin ortadan kaldırılmasına odaklanmaktadır. Bu çalışma nominal döviz kurunu belirleyen faktörleri 77 gelişmekte olan ülkeye ait 20042016 yılları arasındaki verileri kullanarak analiz etmektedir. Ekonometrik tahminlerde panel veri regresyon modelleri kullanılmıştır. Ampirik sonuçlara göre gelişmekte olan ülkelerde düşük nominal döviz kuru seviyelerine ulaşmak için anti enflasyonist para politikalara gerek vardır. Ekonomik büyümenin döviz kurlarını artırıcı etkisi bulunmaktadır. Uluslararası rezerv artışı sağlayamaya yönelik politikaların uygulanması da döviz kurlarını azaltmaktadır.

Anahtar Kelimeler: Nominal Döviz Kuru, Ekonomik Büyüme, Panel Veri Regresyon Modeli

\footnotetext{
${ }^{1}$ This study was supported by Afyon Kocatepe University under Scientific Research Projects (Project No:17. Kariyer. 36)
} 


\section{INTRODUCTION}

Higher nominal exchange rates are one of the main economic problems in developing countries. This problem has not only economic implications but also psychological ones; in developing countries, even if economic indicators are getting better, a rise in the exchange rate can be thought as a result of distorting of economic conditions. This stems from the belief that its potentially negative influence on the main economic variables, such as inflation rate, interest rate, and economic growth and therefore leads to worsening economic expectations. Since nominal exchange rate shocks have adverse effects on the economy, policy makers tend to determine the factors behind it to minimize these effects by applying monetary policies to provide exchange rate equilibrium. These policies are mainly applied by intervening foreign exchange market such as buying and selling of foreign currency.

There are several approaches to the rationale of exchange rate movements in the economic theory. First, the nominal exchange rate may be affected by differences in the yields on financial assets, which is named uncovered interest rate parity theory. According to this approach, an increase in the domestic interest rate or a decrease in the foreign interest rate leads to a nominal appreciation of the national currency. The second approach related to the determinants of nominal exchange rates uses purchasing power parity theory, which points out that the difference of inflation rate between two countries determines the nominal value of their currencies against each other. Considering this approach, it is concluded that the depreciation of the national currency in a country in the long-run stems from a rise in inflation in that country. It is worth noting that the belief that exchange rate movements based on the inflation rate and interest rate can be called the monetary approach.

The accurate diagnosis of high nominal exchange rates allows policy makers to step correctly in order to combat high exchange rate levels by enhancing the effectiveness of the policies applied towards exchange rate stability. This can be provided by estimating determinants of nominal exchange rate movements. For this purpose, we employ panel data model in order to examine the factors affecting the nominal exchange rate by using the panel data of 77 developing countries for the period 2004-2016. This study is organized as follows: Section 2 describes the previous studies on the topic. Section 3 introduces the empirical models and variables used in the empirical investigation. Section 4 describes the estimations. Section 5 presents our conclusions.

\section{PREVIOUS STUDIES ON DETERMINANTS OF NOMINAL EXCHANGE RATE}

In the empirical literature, several studies focused on investigating causality relationships between nominal exchange rates and macroeconomic variables and reached some implications about directions of causality. Kaya (1998), Agenor et.al (1997), Cevher (2016), Çeviş and Kadılar (2001), and Sekmen and Ravanoğlu (2017) examine the causal relationships between nominal exchange rate and several macroeconomic variables. However, since aiming at estimating the parameters of determinants of nominal exchange rate, we focus on the studies in which parameter estimations were made.

Previous studies on the determinants of nominal exchange rate (against USA Dollar) used time series models in estimating parameters. For instance, Kandil (2015) employed a time series model for 19 developing countries and found out different estimations. The empirical findings showed that money supply and imports variables lead to depreciation in the national currency and that investment, exports, and foreign capital variables contribute to appreciation in the national currency. Using monthly time series data for the period of 2006 and 2015, Yurdakul (2016) claimed that capital flows cause an appreciation of the national currency, whereas high prices and the growth of money supply lead to a rise in nominal exchange rate, demonstrating the validity of monetary approach in Turkey in the period examined. Another study about the topic was made by Hsing (2016) by using time series analysis for Hungary data for the period of 2000 and 2014 and found out higher interest rate, economic growth, and low inflation rate lead to an appreciation of the national currency. Similarly, Bouraoui and Phisuthtiwatcharavong (2015) used the time series data between 2004 and 2013 and analyzed the relationship between the USA Dollar and Thailand Baht. Empirical findings demonstrated that the variables of money supply and manufacturing industry index have a positive but not significant effect 
on Thailand Baht, unlike international reserves that have a positive significant effect. In this study, it was also found that although interest rate differential has a negative sign, it is not significant.

Looking at the literature, we detect that short-run factors were applied in the empirical estimations. Hsing (2015a) examined the short term determinants of USA Dollars/Zloty parity for the period 1999- 2003 using quarterly time series data. Empirical findings suggest that an increase in real GDP leads to depreciation of Zloty. However, a rise in interest rate reveals the opposite effect. The other study by Hsing (2015b) investigated the short term determinants of USA Dollars/ Indonesia Rupiah parity for the period of 1997 and 2013 using quarterly time series data. Empirical findings show that an increase in real GDP depreciates Indonesia Rupiah, whereas higher real interest rate appreciates Indonesia Rupiah.

There are also several studies focused on long-term estimations in the literature. Among them, Chiu (2008) analyzed the long term determinants of USA Dollar/ Taiwan Dollar parity for the period 1981-2007 by using quarterly time series data and found out that growth of money supply and an increase in domestic prices to USA prices ratio lead to the higher nominal exchange rate. Nonetheless, it is concluded that international reserves have a mitigating effect on nominal exchange rate levels.

Although short-run and long-run analyzes were separately carried out, several studies made estimations using both time period. For instance, Benazic and Kersan-Skabic (2016) used quarterly time series data for the period of 1998 and 2013 and estimated the determinants of nominal exchange rate (Croatian Kuna/Euro parity). They found out that an increase in international reserves leads to a depreciation of the national currency in the short term. Moreover, they found an unusually positive impact of high inflation rate on nominal value of Kuna both in the short run and in the long run. Kurt and Çalışkan (2016) used monthly time series data for the period of 2013 and 2014 in order to analyze the determinants of the exchange rate in the Turkish economy. They claimed that nominal depreciation of the national currency stems from the growth of money supply both in the short run and in the long run, confirming monetary approach in the period examined. Moreover, they found out the theoretically unexpected relationship between interest rate and the exchange rate for both periods. As a study estimated period analysis, Dropsy (1996) used monthly data between 1973 and 1993 and investigated the determinants of Yen/USA Dollar and Pound/USA Dollar parities. Empirical findings suggest that monetary policy applications have an effect on the exchange rate in the long run and that economic fluctuations and long term interest rates are the main determinants of the exchange rate in the short term and medium term.

\section{ECONOMETRIC MODEL and DATA}

In this study, we use the panel data of 77 developing countries for the period 2004-2016 and employ static panel data methods, such as pooled OLS, fixed effects, and random effects. All data is obtained from the World Bank. The summary statistics are reported in table 1. The variables for some years are not obtained, therefore panel data is unbalanced.

The panel data model applied in the study is constructed as follows:

$$
\operatorname{exc}_{i t}=\alpha_{i}+X_{i t}^{\prime} \beta+\varepsilon_{i t}
$$

Where exc is nominal exchange rate for country $i$ in year $t . X_{i t}$ is a vector of independent variables and $\varepsilon_{t}$ is error term. Independent variables of the model are gross domestic product, money growth rate, inflation rate, interest rate, and international reserves. The nominal exchange rate variable represents the value of the national currency in terms of USA Dollar. Gross domestic product variable is calculated at 2010 prices. The method of estimating the equation is specified by employing various pre-tests. These tests provide empirical evidence about the selection of appropriate estimators which are fixed effects, random effects and pooled ordinary least squares (pooled OLS). In selecting between fixed effects and pooled OLS F test is employed argued by Moulton and Randolph (1989). In selecting between random effects and pooled OLS Breusch and Pagan (1980) LM, Adjusted LM, Score (Bottai, 2003), Honda (1985), and King and Wu (1997) tests are applied. After applying these tests, if we 
reach empirical evidence of not selecting pooled estimators, Hausman (1978) test is employed to determine which of the estimators of fixed effects or random effects is appropriate.

Table 1. Summary Statistics

\begin{tabular}{|c|c|c|c|c|c|c|}
\hline Variable & Definition & Observation & Mean & Std. Dev. & Min & Max \\
\hline $\begin{array}{l}\text { Nominal } \\
\text { Exchange } \\
\text { Rate }\end{array}$ & $\begin{array}{l}\text { Nominal exchange rate (in } \\
\text { logarithmic form) }\end{array}$ & 1000 & 3.54 & 2.62 & -1.54 & 10.00 \\
\hline $\begin{array}{l}\text { Gross } \\
\text { Domestic } \\
\text { Product }\end{array}$ & $\begin{array}{l}\text { Real GDP (in logarithmic } \\
\text { form) }\end{array}$ & 1000 & 24.08 & 2.05 & 18.74 & 29.88 \\
\hline $\begin{array}{l}\text { Money } \\
\text { Growth }\end{array}$ & $\begin{array}{l}\text { Money supply growth rate } \\
\text { (M2,\%) }\end{array}$ & 998 & 16.52 & 13.05 & -14.73 & 121.23 \\
\hline Inflation Rate & $\begin{array}{l}\text { Inflation rate (Percentage } \\
\text { change in consumer prices, } \\
\%)\end{array}$ & 978 & 6.86 & 6.04 & -35.83 & 59.21 \\
\hline Interest Rate & $\begin{array}{l}\text { Interest rate on time } \\
\text { deposits }(\%)\end{array}$ & 987 & 6.39 & 4.17 & 0.17 & 24.27 \\
\hline $\begin{array}{l}\text { International } \\
\text { Reserves }\end{array}$ & $\begin{array}{l}\text { International reserves (in } \\
\text { logarithmic form) }\end{array}$ & 998 & 22.21 & 2.11 & 16.74 & 28.98 \\
\hline
\end{tabular}

Source: World Bank (2017)

Countries: Albania, Argentina, Azerbaijan, Bangladesh, Angola, Armenia, Belarus, Bhutan, Brazil, Botswana, Bulgaria, Brunei Darussalam, Cambodia, Cabo Verde, Chile, China, Colombia, Democratic Republic of the Congo, Congo Republic, Costa Rica, Croatia, Dominican Republic , Egypt, Fiji, Gambia, Georgia, Ghana, Guatemala, Guyana, Haiti, Honduras, Hungary, Indonesia, Jamaica, Kenya, Kuwait, Kyrgyzstan, Lesotho, Liberia, Macedonia, Malawi, Malaysia, Mauritius, Mexico, Moldova, Mongolia, Morocco, Mozambique, Namibia, Nicaragua, Nigeria, Oman, Papua New Guinea, Guinea, Paraguay, Peru, Philippines, Romania, Russia, Rwanda, Samoa Sao Tome and Principe, Serbia, Sierra Leone, South Africa, Sri Lanka, Swaziland, Tajikistan, Tanzania, Thailand, Tonga, Trinidad and Tobago, Turkey, Uganda, Ukraine, Uruguay, Vietnam, Zambia

\section{EMPIRICAL RESULTS}

Estimating panel data model, we first determine appropriate estimators by using several tests. These tests and the coefficients on the regressors are reported in table 2. The first panel of table 2 demonstrates the estimations obtained from the random effects model, fixed effects, and pooled OLS. The second panel of table 2 shows the statistical significance of the models, goodness of fit of the models, and the number of observations. The third panel of table 2 reports the tests to make a decision on selecting appropriate estimators. To prefer between pooled OLS model and fixed effects model we use $\mathrm{F}$ tests. The values of $\mathrm{F}$ test show that the null hypothesis is rejected at significance level of $\% 1$, demonstrating that fixed effect estimator outperforms pooled OLS one. Preferring between pooled OLS and random effects model, we applied Breusch and Pagan (1980) LM, Adjusted LM, Score (Bottai, 2003), Honda (1985), and King and Wu (1997) tests. All test results show that random effects estimator outperform pooled OLS one. In the end, Hausman test should be applied in order to 
determine the appropriate estimators that obtained fixed effects and random effects models. Hausman (1978) test results present that the null hypothesis is rejected and therefore suggest that the fixed effects model should be used in the empirical estimations.

Table 2. Estimations of Panel Data Models and Pre-tests for Estimator Selection

\begin{tabular}{|c|c|c|c|}
\hline Variable & Random Effects & Fixed Effects & Pooled OLS \\
\hline Gross Domestic Product & $0.611 * * *$ & $0.670 * * *$ & -0.153 \\
\hline Money Growth & $-0.002 * * *$ & $-0.002 * * *$ & 0.005 \\
\hline Inflation Rate & $0.005 * * *$ & $0.005 * * *$ & 0.019 \\
\hline Interest Rate & $0.005^{*}$ & $0.005^{*}$ & $0.041 *$ \\
\hline International Reserves & $-0.071 * * *$ & $-0.081 * * *$ & -0.015 \\
\hline Constant & $-9.652 * * *$ & $-10.846^{* * *}$ & $7.069 * * *$ \\
\hline $\mathrm{N}$ & 965 & 965 & 965 \\
\hline Wald $\chi^{2}$ & $57.45 * * *$ & & \\
\hline $\mathrm{F}$ & & $63.42 * * *$ & $5.76^{* * *}$ \\
\hline $\mathrm{R}^{2}$ & 0.26 & 0.26 & 0.029 \\
\hline$F$ test & & $2848.59 * * *$ & \\
\hline Hausman & $25.62 * * *$ & & \\
\hline \multicolumn{4}{|l|}{ Test } \\
\hline B-P LM & $5386.60 * * *$ & & \\
\hline ALM & $4356.41 * * *$ & & \\
\hline Score & $2.6 \mathrm{e}+07 * * *$ & & \\
\hline Honda & & & $73.39 * * *$ \\
\hline King-Wu & & & $26.08 * * *$ \\
\hline
\end{tabular}

Souce: Authors' calculations

*** $1 \%$ and $* 10 \%$ demonstrate statistical significance levels.

B-P LM: Breusch and Pagan LM; ALM: AdjustedLagrangeMultiplier.

The test results reported in table 2 suggest that the fixed effects model seems to be appropriate to estimate the factors that determine nominal exchange rate. The estimations of the fixed effects model are reported in column 2 of table 2. According to the results, the signs of the coefficients on gross domestic product, international reserves, and inflation rate are positive and significant. This conclusion demonstrates that an increase in these variables leads to higher nominal exchange rates. Although seeming to be a positive effect on nominal exchange rate, the interest rate has low significance level. However, the signs of the coefficients on international reserves are negative, which presents an increase in international reserves and money supply decrease nominal exchange rate. To determine that the estimators obtained from fixed effects model are unbiased and consistent, we apply autocorrelation and heteroskedasticity tests. In this study, Modified Wald test is made to test heteroskedasticity (Greene, 2000) and Bhargava, Franzini, and Narendranathan (1982) Durbin-Watson test and Baltagi-Wu (1999) Locally Best Invariant - LBI test are applied to test autocorrelation. In the event that Modified Wald test statistics are significant, the null hypothesis of no heteroskedasticity in the model is rejected. Moreover, if Bhargava et al. (1982) Durbin Watson and Baltagi-Wu (1999) LBI tests are less than 2, the null hypothesis of no autocorrelation is rejected. These test results are reported in table 3. 
Table 3. Autocorrelation and Heteroskedasticity Tests for Fixed Effects Model

\begin{tabular}{l|ccc}
\hline & M-Wald & Bhargava et al. DW & Baltagi-Wu LBI \\
\hline Heteroskedasticity & $12855.05 * * *$ & & \\
& & & \\
\hline Autocorrelation & & 0.398 & 0.797 \\
& & & \\
\hline \multicolumn{2}{l}{ Souce: Authors' calculations }
\end{tabular}

Souce: Authors' calculations

*** $1 \%$ demonstrate statistical significance levels.

Autocorrelation and Heteroskedasticity test results show that there is a problem in the residuals with autocorrelation and no heteroskedasticity. Therefore, the fixed effect estimators would be unbiased and inconsistent. Due to the fact that the residuals obtained from fixed effect have autocorrelation and heteroskedasticity, fixed effects model is estimated with cluster standard errors, and therefore Arellano (1987), Froot (1989) and Rogers (1993) estimators are used. The estimations with robust standard errors are reported in table 4.

According to the results obtained from table 4, the coefficients on gross domestic product and inflation rate are significantly positive, suggesting that they are positively associated with nominal exchange rate. The coefficient on international reserves is significantly negative, demonstrating that high international reserves decrease nominal exchange rates. Although money supply is negatively associated with nominal exchange rate, the coefficient of it has less significance.

Table 4. Estimations of Fixed Effect Model with Cluster Robust Standard Errors

\begin{tabular}{l|c}
\hline Variable & \\
\hline Gross Domestic Product & $0.670^{* * *}$ \\
Money Supply & $-0.002^{*}$ \\
Inflation Rate & $0.005^{* *}$ \\
Interest Rate & 0.005 \\
International Reserves & $-0.081^{* * *}$ \\
Constant & $-10.846^{* * *}$ \\
\hline & \\
\hline $\mathrm{N}$ & 965 \\
$\mathrm{~F}$ & 12.07 \\
$\mathrm{R}^{2}$ & 0.26 \\
\hline Souce: Authors' calculations & \\
\hline
\end{tabular}

Souce: Authors' calculations

$* * * 1 \%, * * 5 \%$ and $* 10 \%$ demonstrate statistical significance levels.

Empirical results show the importance of anti-inflationary policies to provide exchange rate stability in developing countries. In developing countries, lower inflation rates contribute to the appreciation of the national currency. Diminishing inflation rates encourage new investments and increase output as well as attract foreign capital because of its reducing effect on country risk, leading 
to lower nominal exchange rates. However, in the empirical results, it is concluded that higher economic growth associated with higher nominal exchange rates. Accelerating imports due to high economic activities may be a reason for this result. Finally, empirical results show higher international reserves have a diminishing effect on nominal exchange rates. This finding implies that economic policies enhancing exports and international capital contribute to lower nominal exchange rates.

\section{CONCLUSION}

Nominal exchange rate movements have a crucial role in the economic environment for developing countries because many economic indicators related to the financial and real sector are influenced by these movements. Investigation of the determinants of nominal exchange rate allows policy makers to apply effective policies towards lower nominal exchange rates. Our study provides knowledge about which variables should be considered to decrease nominal exchange rates in developing countries. For this purpose, the panel data method was applied in the econometric estimations. The selection of appropriate estimators provides econometric estimations with consistent. In this context, the basic assumptions were tested and then estimations were made with robust standard errors. Empirical findings show that an increase in inflation rate leads to an appreciation of the national currency. This finding is consistent with the studies of Yurdakul (2016) ve Hsing (2016). Therefore, anti-inflationary economic policies seem to contribute to exchange rate stability in developing countries. Further, providing credibility in monetary policy and fiscal discipline can be considered in applying these policies.

Empirical findings show that increases in nominal exchange rate stem from economic growth in developing countries. This finding is consistent with the studies of Hsing (2015a) and (Hsing 2015b). In the economies whose economic growth depends on imports, expansion of economic activities may increase the demand for foreign currency and this leads to higher nominal exchange rates. Nevertheless, economic growth based on capital formation may decrease nominal exchange rates, as increases in the capital formation may have a positive impact on exports and therefore lead to low nominal exchange rates. Empirical estimations show the importance of the effect of international reserves on nominal exchange rates. According to this finding, economic policies encouraging more exports and capital flows may contribute to lower nominal exchange rates. This finding confirms the studies of Kandil (2015) and Yurdakul (2016). The main thought behind it is that more international reserves allow central banks to intervene more effectively in foreign exchange markets.

\section{REFERENCES}

AGENOR, P.R.,McDERMOTT C.J. and ÜÇER, M. (1997). "Fiscal Imbalances, Capital Flows and the Real Exchange Rate: The Case of Turkey", IMF Working Paper, No.97/1.

ARELLANO, M. (1987). "Computing Robust Standart Errors for within Group Estimators", Oxford Bulletin of Economics and Statistics, 49(4): 431-434.

BALTAGI, B. H., and WU, P. X. (1999). "Unequally Spaced Panel Data Regressions with AR(1) Disturbances", Econometric Theory, 15: 814-823.

BENAZIC, M. and SKABIC-KERSAN, I. (2016). "The Determinants of Exchange Rate in Croatia", Eastern Journal of European Studies, 7(1): 125-150.

BHARGAVA, A.,FRANZINI, L. and NARENDRANATHAN, W. (1982). "Serial Correlation and the Fixed Effects Model”, Review of Economic Studies, 49(4): 533-549.

BOTTAI, M. (2003). “Confidence Regions when the Fisher Information is Zero", Biometrika, 90(1): 73-84. 
BOURAOUIA, T. and PHISUTHTIWATCHARAVONG, A. (2015). "On the Determinants of the THB/USD Exchange Rate”, Procedia Economics and Finance, 30: 137-145

BREUSCH, T. S. and PAGAN, A. R. (1980). "The Lagrange Multiplier Test and its Applications to Model Specification in Econometrics", The Review of EconomicStudies, 47(1): 239-253.

CEVHER, E. (2016). "Döviz Kurunun Belirleyicilerinin Koşullu ve Kısmi Granger Nedensellik Testleri ile Araştırılması", (Ed.) YURDAKUL, F., Döviz Kurunun Belirleyicileri: Kısmi ve Koşullu Granger Nedensellik, SETAR, LSTAR, TVAR Modelleri: 105-160, Ankara: Gazi Kitabevi.

ÇEVIŞ, İ. and KADILAR, C. (2001). "The Analysis of the Short-Term Capital Movements by Using the VAR Models: The Case of Turkey”, The Pakistan Development Review, 40(3):187-201.

CHIU, M. (2008). “An Empirical Study on the Long-Run Determinants of Exchange Rate”, Review of Pacific Basin Financial Markets and Policies, 11(3): 389-409.

DROPSY, V. (1996). "Macroeconomic Determinants of Exchange Rates: A Frequency-Specific Analysis", AppliedEconomics, 28: 55-63.

FROOT, K.A. (1989). "Consistent Covariance Matrix Estimation with Cross Sectional Dependence and Heteroskedasticity in Financial Data", Journal of Financial and Quantitative Analysis, 24(3): 333-355.

GREENE, W. (2000). Econometric Analysis, Upper Saddle River, NJ: Prentice-Hall.

HAUSMAN, J. A. (1978). "Specification Tests in Econometrics”, Econometrica, 46(6): 1251-1271.

HONDA, Y. (1985). "Testing the Error Components Model with Non-Normal Disturbances", Review of Economic Studies, 52: 681-690.

HSING, Y. (2015a). "Short-Run Determinants of the USD/PLN Exchange Rate and Policy Implications", Theoretical and Applied Economics, Volume XXII, No. 2(603): 247-254

HSING, Y. (2015b). "Short-Run Determinants of the IDR/USD Exchange Rate: A SimultaneousEquation Model", Global EconomyJournal, 15(3): 311-318.

HSING, Y. (2016). "Determinants of the Hungarian Forint/ US Dollar Exchange Rate", Theoretical and Applied Economics, Volume XXIII, No. 1(606): 163-170.

KANDIL, M. (2015). "On the Benefits of Nominal Appreciations: Contrasting Evidence Across Developed and DevelopingCountries", Borsa Istanbul Review, 15-4: 223-236.

KAYA, Y. T. (1998). Sermaye Hareketleri ve Kisa Vadeli Sermaye Hareketlerinin Modellenmesi: Türkiye Örneği, Ankara: Devlet Planlama Teşkilatı, Yayın No: DPT: 2487.

KING, M. L., and WU, P. X. (1997). "Locally Optimal One Sided Tests for Multiparameter Hypotheses", Econometric Reviews, 16: 131-156.

KURT, Ü and ÇALIȘKAN, Z.D. (2016). "Türkiye Ekonomisinde Döviz Kurlarının Açıklanmasında Parasal Modelin Geçerliliği: ARDL Modeli Uygulaması", Journal of Strategic Research in Social Science, 2(4): 29-40.

MOULTON, B. R. and RANDOLPH, W. C. (1989). "Alternative Tests of the Error Components Model”, Econometrica, 57(3): 685-693.

ROGERS, W.H. (1993). "Regression Standard Errors in Clustered Samples", Stata Technical Bulletin, 13: 19-23.

SEKMEN, F. and RAVANOĞLU, G.A. (2017). "Faiz Haddi ve Para Arzının Döviz Kuru Üzerine Etkisi", Manas Sosyal Araştırmalar Dergisi, 6(4): 333-342. 
YURDAKUL, F. (2016). "Döviz Kuru Modellemesi: Türkiye Üzerine Bir Uygulama”, YURDAKUL, F., Döviz Kurunun Belirleyicileri: Kısmi ve Koşullu Granger Nedensellik, SETAR, LSTAR, TVAR Modelleri: 1-49, Ankara: Gazi Kitabevi.

WORLD BANK (2017). World Development Indicators,

http://databank.worldbank.org/data/reports.aspx?source=world-development-indicators, $(10.10 .2017)$ 